\title{
A Global Education Application in Turkey: A Product Marketing Activity
}

\author{
Şule Egüz ${ }^{1, *}$, Cemil Öztürk², Alper Kesten ${ }^{3}$ \\ ${ }^{1}$ College of Education, İnonu University, Turkey \\ ${ }^{2}$ Ataturk College of Education, Marmara University, Turkey \\ ${ }^{3}$ College of Education, Ondokuz Mayis University, Turkey
}

Copyright $\bigcirc 2018$ by authors, all rights reserved. Authors agree that this article remains permanently open access under the terms of the Creative Commons Attribution License 4.0 International License

\begin{abstract}
This article describes a "Product Marketing Activity" prepared for teaching one of the concepts in the unit on global education, "Our Country and the World," which is a part of the 6th grade Social Studies teaching program in Turkey. The objective of the research was to determine the multiple perspectives with which students look at global issues related to the economy and how the proposed activity can influence the development of their skills in using communications technologies. The principal reason for making use of this activity was based on the knowledge of the importance of economic relations in the world and the fact that qualitative discussions with the students showed that this activity was one that the students found most entertaining. It is considered that designing activities for students that are supported by communications technologies may be effective in helping them gain a global perspective.
\end{abstract}

Keywords Global Education, A Global Perspective, Marketing Activity

\section{Introduction}

Often used synonymously and interchangeably with terms such as global learning, global citizenship, the general concept of global education refers to a non-centralized and diverse movement [2-19]. Global education develops the knowledge, skills and attitudes that are fundamental in having a say and becoming an active participant in the world order, which is a multicultural, interdependent structure that is characterized by international competitiveness [15]. In this sense, global education has a substantial context in research and is a reflection of the physical world. It is related to the need of societies that are becoming more and more dependent upon each other to engage in reciprocal relations [13]. In this context, the purpose of global education is to support individuals in acquiring the necessary qualifications for life among the world society, in coping with complex life conditions and the uncertainties of future, and to shape the education with democratic policies, to guide students in creating a peaceful world and providing teachers with more opportunities [20].

In decision-making processes related to education, global education leans on a school-based administrative style that requires close contact with the student [12]. In this regard, the school must create an organizational culture that will transmit to the individual the universal values of a globalizing world together with the values that protect national identity without conflicting with universal concepts. Moreover, the school must not only preserve the organizational culture it has adopted but must also be open to changes that occur in the international sphere [21]. This is because in this global age, a school is not a building and the classroom is not only made up of four walls, but each of these is mere pieces in the large process of the production of knowledge. From this perspective, it can be said that the world itself is a "global school" and anywhere we might be carries the characteristics of a classroom $[3,5]$.

The importance of considering education in its universal dimensions and recognizing the significance of the efforts to integrate the countries of the world in global education are matters that are steadily coming to the fore. The most suitable area of basic knowledge in which global education can be carried out is the field of Social Studies [18]. The goal of Social Studies education in Turkey has been to create effective, problem-solving citizens that can adapt to the continuously changing conditions of the country and the world by making knowledge-based decisions [16]. This is because Social Studies education can provide the individual with the agency to evaluate other global dynamics and models of change outside of one's own cultural perspective [7]. In this context, Social Studies education offers individuals the means to become aware of universal issues, events, problems and phenomena and supports them in achieving global awareness.

Global education offered through the medium of 
communications technologies seeks to equip students with the knowledge, skills and competences needed to achieve a multiple perspective, the capability to understand and respect other cultures, learn about global events and issues and comprehend that the world is an interconnected system [4]. In line with this, the activities conducted in the Social Studies classroom and the communications technologies used play an important role in concretizing many abstract topics appearing in the activity content, making them more comprehensible, achieving a more effective learning process and helping students to develop their skills. Although there seem to be elements in Turkey's Social Studies curriculum that support global education, as [1] has said, there are still no activities included in the current program that is focused on developing the "multiple perspective" that is so important in the approach to global education [1]. Learning in the context of global education in Turkey has been included in the Social Studies Program for the 4 th, 5 th, 6 th and 7 th grades. The recommendations for teaching these grades consist only of making use of newspaper articles. Meanwhile, new communications technologies have developed to a stage where their contributions to strongly impacting learning and teaching processes in communities have necessitated the use of these technologies in global education.

In the 6th grade curriculum, there are a total of 5 learning outcomes targeted in the unit on Our Country and the World. A separate activity has been designed for each learning outcome. This article describes the activity that was carried out for the purpose of learning about the economy, based on the fact that the globalization and international competition observed in economics is steadily growing. Indeed, economic developments in any region of the world, adverse events or economic crises affect the economies of all countries over the globe. In this context, even the world's most developed countries have chosen to act in cooperation with other countries. It is important therefore from the standpoint of global education that children understand the global significance of economic activities from an early age. It is in this context that this study reviews the "Product Marketing Activity," which was used in the technology-supported Social Studies teaching program that targeted learning outcomes related to global education. The objective of the research was to determine the multiple perspectives with which students look at global issues related to the economy and observe how the activity can influence the development of their skills in using communications technologies.

\section{Materials and Methods}

\section{Study Group}

The study group comprised 24 girls and 20 boys, a total of 44 sixth grade students from two classes of a middle school in Turkey's Samsun province during the 2014-2015 academic year whose socioeconomic and academic standing (grade averages and achievement averages in different courses) were found to be similar. The students making up the sample group volunteered to participate. Maximum variation sampling, a type of purposive sampling, was employed to determine the activity groups in the study. The main objective here was to create a relatively small sampling and define the maximum degree of possible variations for the problem at hand in order to eliminate the researcher's risk of making a "systematic error" [14-22]. In line with this, the students were recruited into a total of 8 groups with at least 4 , at most 6 students in each group at the upper, average and lower levels, designated in this way on the basis of their academic achievement, their achievement in their performance homework and their class attendance in the "Product Marketing Activity" developed by the researchers. The academic achievement levels of the students in the groups were determined based on the opinions of their classroom teachers, the Turkish teacher and the current Social Studies teacher who was conducting the research activity. The 4 groups' activity was selected as the goal (Group 1-Upper, Group 2Average, Group 7-Average, Group 8-Lower).

\section{Data Collection}

Eleven class plans were drawn up and implemented within the scope of the research, using communications technologies (newspapers, television, video and news blogs) to produce learning outcomes in the area of global education. The unit "Our Country and the World" comprises 5 topics and 5 learning objectives. Five different activities were designed, one activity for each topic in the unit. The "Product Marketing Activity" was conducted at the end of the topic in the unit titled "Economic Relations." The principal reasons for making use of only the "Product Marketing Activity" in this study was that the qualitative discussions with the students indicated that this was the activity they would enjoy the most and also because of the knowledge that economic relations are an important issue around the world.

The marketing strategy mapped out for a product creates a competitive environment that is built around elements such as advertising campaigns and the features of the product itself. Global markets are markets that carry finished products that meet the needs of the entire world. These are the petroleum, food, metals and derivatives markets. In this context, some products were first shown to the groups as part of the activity--toy cars, fruit and vegetables, hazel nuts, fabrics-sweaters (textile products), cotton, and mobile phones. The groups were then asked: "If you were to engage in selling one of these products, which one would you choose to sell?" Then, based on the choices of the groups, each was assigned a product and was asked to design a poster for it. The groups were then asked to think of a film scenario for a 1-minute advertisement and then to act out that scenario in front of the class Furthermore, to develop the students' skills in using 
communications technologies and to help them in the creation of ideas in the activity, they were given the opportunity to view some advertising films produced in Turkey and abroad about automobiles, food, apparel and mobile phones. At the end of the activity, the groups were asked a series of semi-structured questions as part of the research (Can you explain why you wanted to produce an advertising film? Which elements did you use to convince the viewer? Who was your target audience? Why did you choose this particular target audience? What was your slogan? Would you want to broadcast your advertising film on a national or an international channel? Why did you prefer a national or an international channel?). In addition, 10 students who participated in the activities were asked questions on activities that were prepared in the scope of the unit for the purpose of determining which activity was liked most; and thus, the collection of the qualitative data were finalized. The interviews were recorded with a voice-recording device. The interviews were made in a class where there was no lesson between 10-15 minutes, and no interventions that could affect the data collection process in a negative manner were made to the participants. 3 of the participants who were included in the interviews were selected from upper level (K5, K8, K10), 4 participants were selected from medium level (K1, K3, K4, $\mathrm{K} 9$ ), and 3 participants were selected from lower level (K2, $\mathrm{K} 6, \mathrm{~K} 7$ ) group. By considering the study ethics, the names of the participants were not used directly, and were coded as $\mathrm{K} 1 \ldots \mathrm{K} 10$.

\section{Data Analysis}

The researchers first classified the performance products that emerged from the "Product Marketing Activity" according to target groups. Two specialists in the field and one Social Studies teacher evaluated the performance of the target groups using the scoring rubric that had been drawn up. Rubrics are scoring designs with instructions that a teacher or another evaluator has developed to analyze the work or products of students
[11]. In this context, the effectiveness performance of the target groups was assessed by the two specialists and Social Studies teacher on the basis of 3 different performance levels shown on the scoring instructions that were developed ( $1=$ Poor, $2=$ Average and $3=$ Very good). The mean scores assessed by the specialists and teacher were calculated and presented in the form of a table, after which the researchers analyzed the products in the activity using the descriptive analysis technique that is a method of qualitative research. The viewpoints of the participants on the activities organized in the scope of the study were analyzed by using the descriptive analysis technique.

\section{Findings}

It can be said that the communication texts that children are most familiar with and respond to the best in communication environments are advertisements [17, $\mathrm{p}$ : 323]. It was in this context that the students were given the "Product Marketing Activity" to engage in at the end of the second topic of "Economic Relations" in the unit "Our Country and the World." In this activity, the groups were shown previously designated products and asked, "If you were to engage in selling one of these products, which one would you choose to sell?" The product that was most commonly chosen among the groups was mobile phones and the one that drew the least interest was fabric. The groups then designed and displayed before the class a poster and advertising film scenario based on the products that they had chosen. After this activity, each group was asked a series of semi-structured questions. The questions, "Would you want to broadcast your advertising film on a national or an international channel? Why did you prefer a national or an international channel?" were considered particularly important in terms of grasping an idea of the students' global perspective in a steadily shrinking world. Table 1 reveals the responses of the groups and the reasons for their answers.

Table 1. The channel chosen for broadcasting the advertisement and why

\begin{tabular}{|c|c|c|}
\hline GROUPS & CHOSEN CHANNEL & WHY \\
\hline Group 1 & $\begin{array}{l}\text { National/ } \\
\text { International }\end{array}$ & $\begin{array}{l}\text { "We would broadcast them on both national and international channels. But it would be best to } \\
\text { broadcast them on national channels. Because the hazelnuts of Erikli Village are only enough for } \\
\text { us." }\end{array}$ \\
\hline Group 2 & National & $\begin{array}{l}\text { "'We would broadcast it on national channels. Because they're of good quality and we would want } \\
\text { Turkish people to have them." }\end{array}$ \\
\hline Group 3 & International & $\begin{array}{l}\text { "We would want to broadcast it on international channels. If there's no field in our country, the } \\
\text { product would rot. Our country's economy will flourish and we will benefit." }\end{array}$ \\
\hline Group 4 & International & $\begin{array}{l}\text { "We would broadcast it on the international channels. Hazelnuts are already one of the foods we } \\
\text { export the most. It will draw people's attention right away." }\end{array}$ \\
\hline Group 5 & International & "We would broadcast it on an international channel; it would promote our country." \\
\hline Group 6 & International & $\begin{array}{l}\text { "We would broadcast it on an international channel. We know about the cars of other countries. } \\
\text { Other countries should get to know and buy the cars of our country; our exports would increase." }\end{array}$ \\
\hline Group 7 & International & $\begin{array}{l}\text { "We would want to broadcast it on international channels. This way we would make a lot more } \\
\text { money." }\end{array}$ \\
\hline Group 8 & International & $\begin{array}{l}\text { "Let it be an international channel. And let foreigners use our goods. That way, their money will } \\
\text { stay with us." }\end{array}$ \\
\hline
\end{tabular}


When the responses of the groups are reviewed in Table 1 , it can be seen that only Group 1 said that they wanted to broadcast the advertisement on both a national and an international channel. More commonly, the students wanted to broadcast on a national channel. As a reason for this, thinking that they would only be selling the hazelnuts from their own village, they were afraid that it would not be enough for the other countries in the world. Because of this, they were unable to display a global perspective in the real sense. In Group 2, the students said that they wanted their advertising film to be broadcast only on the national channels because the products they advertised were of the best quality. They too were unable to exhibit a global perspective. It is true however that in the new world order, what is expected of individuals is not to focus on local events and developments and become limited to national borders but to approach matters with a global perspective and to gain the identity of a world citizen in this way. Indeed, in today's world, new technologies are removing the boundaries between countries [9]. In this context, the other 6 groups gave a single answer and stated that they wanted their advertising film to be broadcast on an international channel. Therefore, their views, as shown in Table 1, displayed a global perspective. In the voting that took place among the groups in the "Product Marketing Activity," the poster that was most liked belonged to Group 1 and the most liked advertising film scenario belonged to Group 7.

The scoring instructions regarding the skills with which students were able to use communications technologies in their learning about global education were assessed by 2 experts in the field and the Social Studies teacher on the basis of appropriateness to the activity, subject/content knowledge, use of communications technologies and associations with global education, adequacy of visual support and organization. Table 2 displays the scores and means calculated by the experts in accordance with the performance subscales in the instructions.

Table 2. Scores and means given by the experts to the group's activity products within the scope of the "product marketing activity"

\begin{tabular}{|c|c|c|c|c|}
\hline \multirow{2}{*}{ Expery } \\
Groups & \multicolumn{4}{|c|}{$\begin{array}{l}\text { PRODUCT MARKETING ACTIVITY } \\
\text { (ACTIVITY 2) }\end{array}$} \\
\cline { 2 - 5 } & $\begin{array}{c}\text { Group 1 } \\
\text { (Upper) }\end{array}$ & $\begin{array}{c}\text { Group 2 } \\
\text { (Average) }\end{array}$ & $\begin{array}{c}\text { Group 7 } \\
\text { (Average) }\end{array}$ & $\begin{array}{c}\text { Group 8 } \\
\text { (Lower) }\end{array}$ \\
\hline Expert 1 & 15 & 8 & 9 & 7 \\
\hline Expert 2 & 15 & 8 & 11 & 6 \\
\hline Expert 3 & 15 & 7 & 9 & 6 \\
\hline TOTAL & 45 & 23 & 29 & 19 \\
\hline MEAN & 15 & 7.67 & 9.67 & 6.37 \\
\hline
\end{tabular}

According to the mean values given in Table 2, Group 1 was at a very good level, Group 7 was average, and Group 2 and Group 8 were at poor levels. The details of the 4 groups' activity appear below in terms of the lower, average and upper academic levels previously determined for the "Product Marketing Activity."

\section{Group 1 (Upper Level)}

Group 1 chose hazelnuts as its product for the activity and designed a poster and film accordingly. The experts evaluated the advertising poster that the students prepared on the basis of the scoring instructions. At the end of the scoring, the group received a full rating and their mean was found to be 15 , showing that the exercise had been accomplished at a very good level. The advertising poster prepared by Group 1 for the "Product Marketing Activity" for the unit on Our Country and the World can be seen below.

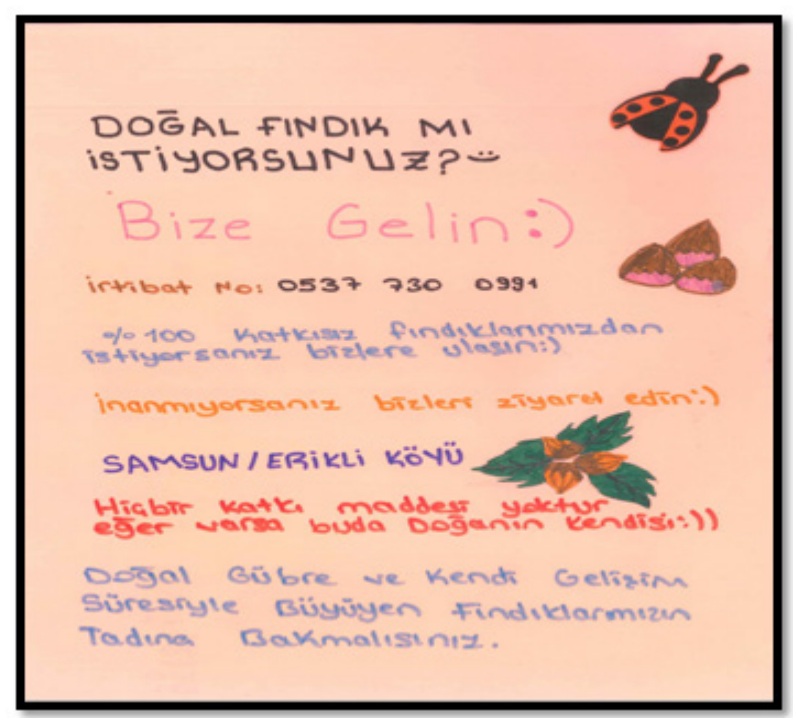

Figure 1. First group activity sheet

As is known, it is becoming steadily more difficult all around the world to reach organic foods. Consumers thus act very meticulously to inquire about the products they buy to make sure that they are reliable. With this as their starting point, Group 1 created an advertising slogan to emphasize the organic nature of their product and put this on their poster. Additionally, they visually enhanced the poster with appropriate drawings. The poster that Group 1 produced was selected the most liked advertising poster in the voting between the groups.

The group also designed an advertising film scenario for the product they had chosen and played this for the class. First one of the 5 group members asked the others in the advertisement, "Do you want natural hazelnuts?" Then after receiving an answer of "yes" from each of the other group members, the student asking the question took out a fistful of hazelnuts from a bag and after stating, "There are no additives in our natural hazel-nuts. If there is, it's only nature itself," the student offered some nuts to the other group members. And after the others all said in unison, "And natural hazelnuts are the best," the film ended.

At the end of the advertising film, the group was asked the following questions: "Could you tell us about why you 
produced this film? Which elements did you use to convince viewers? Who was your target audience? Why did you choose this particular target audience? What was your slogan? Would you want to broadcast your advertising film on a national or on an international channel? Why did you prefer a national or an international channel?" The first question about why the students made the film aimed at finding out the group's objective. Group 1 answered the question by saying, "We produced it to promote our natural hazelnuts" and continued to say that the film's goal was to provide information about the product. They pointed out that to convince viewers, they emphasized that the hazelnuts came from Erikli Village so that it was clear that the products were organic. Additionally, the group chose to address their advertising film to children as their target audience based on their belief that the film could perhaps make a positive change in the children's habits, especially in terms of correcting their bad eating habits. In promoting the products, they used the slogan "If there are any additives in our hazelnuts, it's only nature itself," They stated that they wished to broadcast their advertising film on both a national and an international channel but they believed that broadcasting on a national channel would be more advantageous.

\section{Group 2 (Average Level)}

Group 2 chose fabric as its product for the activity and designed their poster and film accordingly. The experts evaluated the advertising poster that the students prepared on the basis of the 5 categories mentioned in the scoring instructions. At the end of the evaluation, the group's mean score was calculated to be 7.67 and the project was found to be at a poor level. The advertising poster prepared by Group 2 for the "Product Marketing Activity" for the unit on Our Country and the World can be seen below.

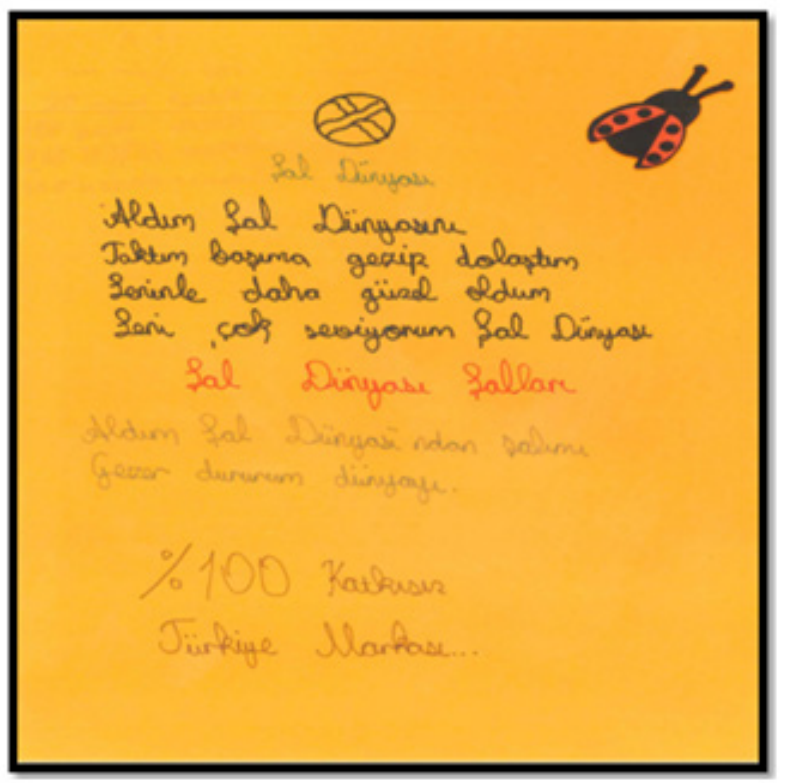

Figure 2. Second group activity sheet
A look into the poster prepared by Group 2 shows that the group had not included many visuals but that they had tried to strengthen their project's message with a four-line rhyme that they wrote. The group also designed an advertising film scenario for the product they had selected. In the advertising film they prepared, one of the group's 5 members used the fabric as a shawl and this student stood out in the middle of the other group members, reading out the four-line rhyme that they had put on the advertising poster. The student reading out the poem waited for the other members of the group to repeat the rhyme. At the end, the students called out the last line of the poem in unison, "We love you very much, Shawl World." Later the group's other members asked the student with the shawl the following questions: "How much is it? Is the fabric cotton? Does it come in other colors? Is it machine-washable?" In completing the film, the student in the middle with the shawl says, "It's $100 \%$ made in Turkey, the price is reasonable, and it's of good quality. Get your shawl too from Shawl World and make your contribution to the Turkish economy."

As in the previous group, the same questions were asked of Group 2 at the end of the film. As it is known, one of the characteristics of advertising is its capacity to support customized sales programs. In this context, the group members said that they had designed the film with the goal of selling the product and making money. Additionally, they said they wrote the rhyme to make the film more convincing for viewers and that their target audience was meant to be women and particularly mothers. It is important that an advertisement transfers information in the briefest and most striking way, making use of language that will make it easy to remember. In line with this, the group's slogan, "I got my shawl from Shawl World and I'm traveling around the world" was impressive because it sent a clear message to the target audience and provided a catchy slogan that was an important step in reaching a bigger audience. On the other hand, because the group said that they preferred to broadcast the film only on a national channel, their efforts inevitably were limited to the local level.

\section{Group 7 (Average Level)}

Group 7 chose mobile phones as its product for the activity and designed their poster and film accordingly. The experts evaluated the advertising poster that the students prepared on the basis of the criteria mentioned in the scoring instructions. At the end of the evaluation, the group's mean score was calculated to be 9.67 and the project was found to be at an average level. The advertising poster prepared by Group 7 for the "Product Marketing Activity" for the unit on Our Country and the World can be seen below. 


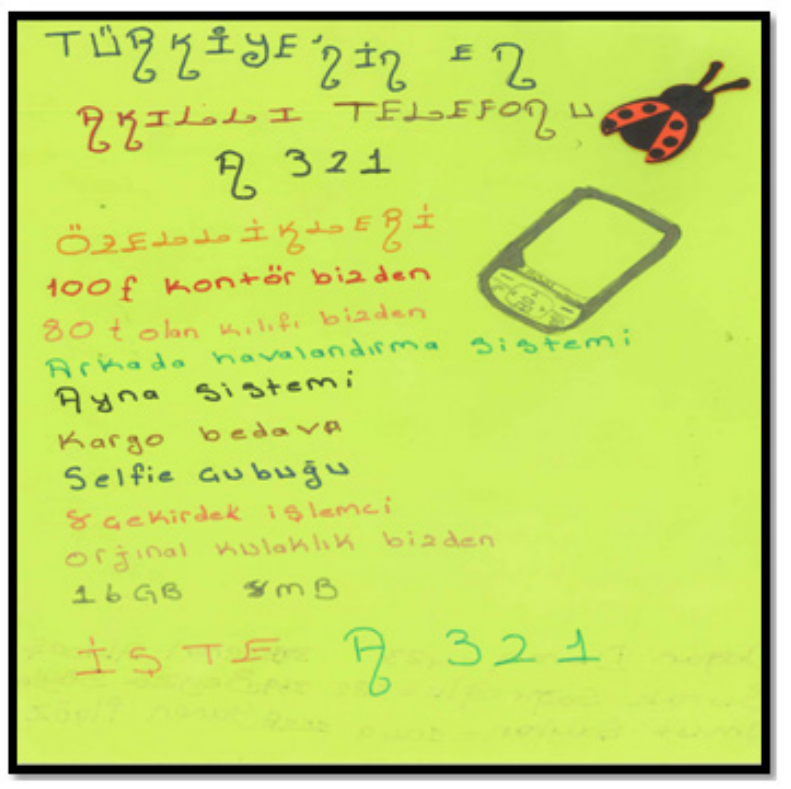

Figure 3. Seventh group activity sheet

Among today's communication technologies, the mobile phone is especially popular among young people and holds an important place in many people's lives. Accordingly, among the products that were brought into the classroom, the mobile phone was the one that caught the most interest. Group 7 made the mobile phone its choice and so they designed their advertising poster and film accordingly. In their poster project, Group 7 first listed the features of their own phone brand and put forth a product that displayed a steering force that would have an impact on people's selection of and decision about the product. The group members designing the advertising film settled upon the scenario below: One of the members of the group borrows an A321 brand phone and accidentally drops it into a container that is supposedly filled with water, driving the owner of the phone and the other group members into a panic. The owner of the phone then says, "Don't worry, the A321 phone has a ventilating system on the back. Nothing happened, don't panic, this is Turkey's smartest phone." After calming down the other students in this way, three in the group complete the scenario by calling out 3 different features of the phone.

The other groups ask Group 7 questions about their advertisement. One of these questions was "Why did you produce this advertising film?" The group answers by promoting the A321 brand mobile phone by describing its quality, remarking that they used the container supposedly filled with water in order to convince viewers. Group 7 pointed out, unlike the others, that they had chosen affluent people as their target group. The slogan for their advertising film was "Be smart, buy Turkey's smartest phone" and the group members said that they wanted to broadcast this film on international channels because they thought it would resound more strongly on international platforms. Group 7 at the same time was voted the group with the most successful scenario for its advertising film by the other groups.

\section{Group 8 (Lower Level)}

Group 8 chose automobiles as its product for the activity and designed their poster and film accordingly. The experts evaluated the advertising poster that the students prepared on the basis of the dimensions mentioned in the scoring instructions. At the end of the evaluation, the group's mean score was calculated to be 6.37 and the project was found to be at a poor level. The advertising poster prepared by Group 8 for the "Product Marketing Activity" for the unit on Our Country and the World can be seen below.

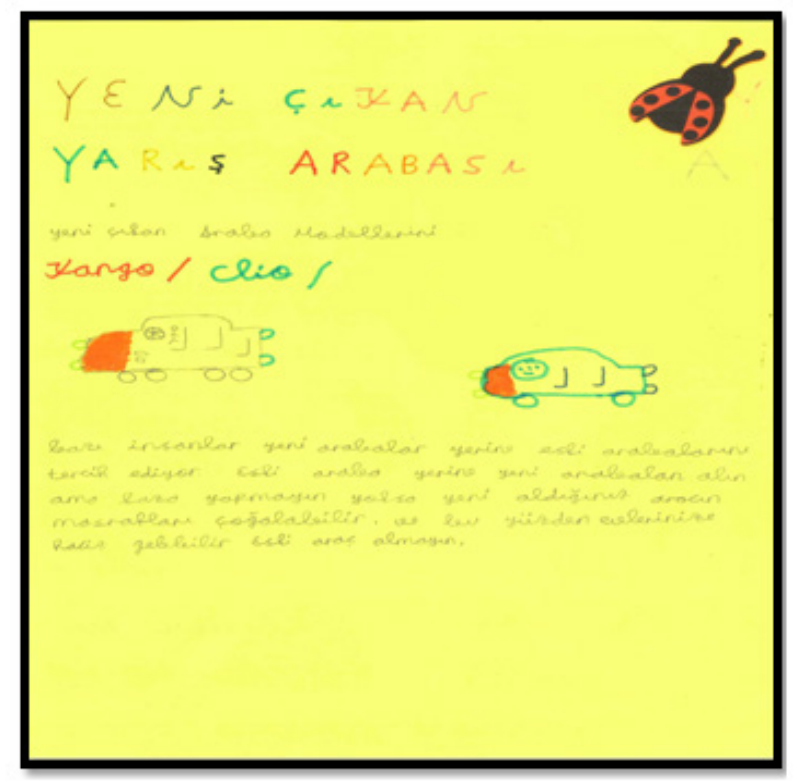

Figure 4. Eighth group activity sheet

Preferring to work on automobiles as a product, Group 8 first designed an advertising poster. When designing a poster, the used colors must be striking and in harmony with the character of the product. Group 8 chose yellow as the color they thought would be most eye-catching from among the different colors of poster paper, and they designed their poster using this color. The group decided to display a social perspective on their poster and so they cautioned consumers to drive carefully and not get into too much debt. In their film-designing project, the group picked out one of the group members to act in the film as they told the story of an individual whose previous car was old and expensive, relating how this person's car had to be confiscated because he could not pay the debt on it. Later in the film all of the group members walk around the classroom with books in their hands, using them as steering wheels, and chant altogether, "Haven't you heard, the new racing cars are not only inexpensive but they were made in Turkey," thus ending the film.

Questions were then asked of Group 8 about the advertising film scenario that they had created and why they had produced a film of this kind. The group answered 
that the brand of car they were promoting was inexpensive and the film was designed to emphasize that everyone could the owner of a car. To convince viewers, the group members stressed in the advertising film that the car should be driven safely without bumping into anything; the target audience constituted fathers and people with lesser economic means, to whom the film message was conveyed that no one needed to be without a car. Additionally, the group members who devised the slogan "The new racing cars are both inexpensive and also made in Turkey" for the advertising film stated that they wanted to have the film broadcast on an international channel. In the explanation of why they wanted this, they said that it was important to reach people on an international platform so that other countries recognized that there were Turkish-made cars available and the level of our export volume could be raised in this way. To have a say in a globalizing world, economic development must take place and exports should lead the economy. In this context, the group members' calling attention to exports as a main factor in achieving the target Turkey has set for itself in its pursuit of heightened development was an accurate conclusion to draw.

\section{The Reflections of the Activities on Students during the Teaching of the Unit}

If the activities that would be applied in the unit are organized in a form that might facilitate the reaching targets status of students in a clear manner, students might participate in the activities in a more motivated manner and more eagerly. In this context, it is necessary that the activities in units are designed well in a manner that is suitable for the requirements of the modern age and include tools and materials. In this section, the participants were asked the following questions on educational program and were prepared for the teaching of the acquisitions on global education in Social Sciences Classes by using communication technologies; "What can you say about the activities we performed in the 'Our Country and the World' Unit?" and "Which activity did you enjoy doing most?" The distribution of the answers given by the participants according to the activities they chose is given in Table 3 .

Table 3. The best loved activities in our country and the world unit

\begin{tabular}{|c|c|}
\hline $\begin{array}{c}\text { THE BEST LOVED ACTIVITY IN THE } \\
\text { UNIT }\end{array}$ & PARTICIPANTS \\
\hline Activity of Inviting to the City & $\mathrm{K} 2, \mathrm{~K} 9$ \\
\hline Product Marketing Activity & $\mathrm{K} 1, \mathrm{~K} 3, \mathrm{~K} 6, \mathrm{~K} 7, \mathrm{~K} 10$ \\
\hline Newspaper Page Design Activity & $\mathrm{K} 8$ \\
\hline Help Campaign Activity & $\mathrm{K} 4$ \\
\hline Addressing the World Activity & $\mathrm{K} 5$ \\
\hline
\end{tabular}

When Table 2 is analyzed it is seen that half of the participants intensified on 'Product Marketing Activity'. As a matter of fact, the changing world conditions have made children become important consumers in our present day. In this context, the intensity of the participants in Product Marketing Activity is an expected result in our present day in which marketing messages are more than one place with the help of technology. In this context, K7 said, "I loved the activity in which we introduced the products, and in which we performed export and import. We did some advertisement poster design. There are always the advertisements of foreign products on TV. We deal mainly with import. Since we have less export activities, the income resources become scarce in our country. We need to sell products to other countries. In the activity, I think that part in which we sold the products we selected to other countries", added that s/he followed marketing messages in the media, and emphasized that export was important for the country. Below are some viewpoints of the participants on the most loved activity in the unit:

K3: "Ma'am, I enjoyed the telephone introduction activity best. We cared more because we would sell to other countries, and because we thought that they would not purchase a product if they did not understand and like. We used the elements that would attract their attention in the advertising clip" (Product Marketing Activity).

K6: "The export and import activity was the most enjoyable one, I liked it very much. We did our own advertisement clip with our own ideas. It is really strange. We wrote a song for our advertisement clip. We had chosen 'cloth' in this activity. We would write an Acrostics, but we could not write because we did not remember anything. If we had more time, we would do this as well" (Product Marketing Activity).

In the light of the viewpoints of the students, it was determined that the most liked activity in the scope of the unit was 'Product Marketing Activity', and the participants liked the practices and activities in general and enjoyed themselves.

\section{Conclusions}

It appears important that in process-based teaching and learning activities, students are able to structure knowledge, search for solutions to problems and take responsibility during the process for cooperation and individual performance within group work [6]. In reviewing the "Product Marketing Activity" that uses communication technologies within the context of global education, the evaluation made by the experts and teachers regarding the work of the 4 groups, whose academic achievement had been defined as being at upper, average and lower levels, resulted in the determination that the performance of the students in terms of the appropriateness of the products used by the students to the desired learning outcome, the students' knowledge of subject/content, their use of communications technologies and their ability to associate 
what they learned with global learning, the adequacy of their visual supports and their organizing abilities generally appeared to be on the levels of very good, average and poor (Group 1 was very good, Group 7 was average, Group 2 and Group 8 were poor). Therefore, the scoring of the activity products was partially in parallel with the academic achievement of the target groups as initially determined.

Activities in which students are at the center of the learning setting make individual learning easier. In Turkey, however, classroom activities are usually conducted on the cognitive level and cognitive behavior is the learning outcome in this case. This kind of behavior however makes it difficult for the individual to transfer what has been learned into everyday life [10]. In contrast, the activity used in this study, the "Product Marketing Activity," offers students both the opportunity to have a real experience and to make a connection with the globalizing world. Moreover, by designing the activity in a manner that incorporates the use of communications technologies, learning is made easier by keeping the student in the center of the learning environment. The fact furthermore that seven of the 8 groups made it known that they wanted to broadcast their advertising films on international channels indicated that the students had adopted a global perspective. Indeed, in countries that have a predominantly young population like Turkey, children constitute an important market and they have become a significant target audience for advertising films [8]. It is clear that advertising films that affect our lifestyles in the process of globalization and exhibit catchy messages and strong advertising constructs activate students' creativity. This was seen in the "Product Marketing Activity" and was the reason that this activity was more entertaining for the students compared to other activities.

In a globalizing world, the individual should not only follow the immediate surroundings but also be closely aware of the rest of the world, recognizing that the world is a place that is a common living space for everyone. When it is considered that communications technologies have rapidly advanced in today's world and that students are becoming familiarized with communication technologies at younger and younger ages, it is important in terms of global education to acknowledge the capabilities of this younger age group and integrate activities to reflect the outcomes of global learning. In the activity prepared for this research, the students were guided into using communications technologies to access knowledge and to transform this knowledge into skills. For this reason, the activity products were successful in providing the means for achieving this.

\section{REFERENCES}

[1] Açıkalın, M. (2010). Influence of global education on the
Turkish social studies curriculum. The Social Studies. 101: 254-259.

http://www.tandfonline.com/doi/pdf/10.1080/00377991003 774887.

[2] Alger, C. F., Harf, J. E. (1985). Global education: Why? For whom? About what? Washington, DC: American Association of Colleges for Teacher Education. http://files.eric.ed.gov/fulltext/ED265107.pdf.

[3] Ar1, E. (2011). Temel kavramlar (Basic concepts). In. Öğrenme öğretme kuram ve yaklaşımları (Learning, teaching theories and approaches), ed. S. Büyükalan-Filiz. Ankara: Pegem Akademi.

[4] Bozkurt, M. (2013). Sinıf öğretmenlerinin sosyal bilgiler dersi bağlamında küresel eğitime ilişkin görüşleri (Primary school teachers? views on global education within the context of social studies course). Unpublished master's thesis, Anadolu Üniversitesi: Eskişehir.

[5] Carnoy, M., D. Rhoten. (2002). What does globalization mean for educational change? A comparative approach. Comparative Education Review, Vol. 46, No.1, 1-9.

[6] Duman, B. 2002. Küreselleşme sürecinde öğrenme öğretme nasıl yapılmalıdır? (How should learning - teaching be done in the globalization process?). Çukurova Üniversitesi Sosyal Bilimler Enstitü Dergisi, Vol. 9, No. 9, 40-55.

[7] Hanvey, R. G. (2001). An attainable global perspective. In. Changing perspectives on international education, ed. P. O'Meara, H. D. Mehlinger and R. M. Newman. USA: Indiana University Press.

[8] Karaca, Y., Pekyaman, A., H. Güney. (2007). Ebeveynlerin televizyon reklam içeriklerinin çocuklar üzerindeki etkilerini etik açıdan algılamalarına yönelik bir araştırma (A study on parent's ethical perceptions of the effects of TV advertising contents on children). Sosyal Bilimler Dergisi, Vol. 9, No. 2, 233-250.

[9] Kesten, A. (2007). The internet, globalization, and possible problems of Turkish teachers. Dokuz Eylül Üniversitesi Buca Eğitim Fakültesi Dergisi, No. 22, 7-14.

[10] Köse, E. (2004). İlköğretim öğrencilerinin ders dış1 etkinlikleri tercih etme nedenleri (Reasons for primary school students to opt for extracurricular activities). https://www.pegem.net/dosyalar/dokuman/75.pdf.

[11] Kutlu, Ö., Doğan, C. D., Karakaya, İ. (2009). Ölçme ve değerlendirme (Quantification and evaluation). Ankara: Pegem Akademi.

[12] Lee, N. N. M. (2002). Eğitimde küresel eğilimler (Global trends in education). Educational Sciences: Theory \& Practice, Vol. 2, No.1, 155-168.

[13] Mason, R. (2003). Global education: Out of the ivory tower. In Handbook of distance education. ed. M. G. Moore and W. G. Anderson. London: Hamilton Printing Company.

[14] Maxwell, J. A. (1996). Qualitative research design: An interactive approach. California: SAGE Publications.

[15] Merryfield, M. (1995). Teacher education in global and international education. http://files.eric.ed.gov/fulltext/ED384601.pdf. 
[16] Öztürk, C. (2009). Sosyal bilgiler: Toplumsal yaşama disiplinlerarası bir bakış (Social studies: An interdisciplinary outlook on social life. In Sosyal bilgiler öğretimi. (Teaching social studies), ed. C. Öztürk. Ankara: Pegem Akademi.

[17] Pembecioğlu, N. (2006). İletişim ve çocuk (Communication and children). Ankara: Ebabil Yayınları.

[18] Sözer, E. (1998). Sosyal bilgiler programını amaçları, ilkeleri ve temel özellikleri (The aims, principles and basic characteristics of the social studies program). http://w2.anadolu.edu.tr/aos/kitap/IOLTP/2295/unite02.pdf

[19] Standish, A. (2014). What is global education and where is it taking us? The Curriculum Journal, Vol. 25, No. 2,166-186.

[20] Scheunpflug, A. \& Asbrand, B. (2006). Global education and education for sustainability. Environmental Education Research, 12(1), 33-46.

[21] Tezcan, M. (1984). Okulda başarısızlık ve önlenmesi (Failure and prevention in school). Ankara Üniversitesi Eğitim Bilimleri Fakültesi Dergisi, Vol. 17, No.1, 385-388.

[22] Yıldırım, A. \& Şimșek, H. (2013). Sosyal bilimlerde nitel araştırma yöntemleri (Qualitative research methods in the social sciences). Ankara: Seçkin Yayıncılık. 